\title{
Sustainability, Accountability and Democracy: Ireland's Troika Experience
}

\author{
Sean Barrett ${ }^{a}$, Shaen Corbet $^{b}$, Charles Larkin ${ }^{a *}$ \\ ${ }^{a}$ Trinity Business School, Trinity College Dublin, Dublin 2 \\ ${ }^{b}$ DCU Business School, Dublin City University, Dublin 9 \\ *Corresponding Author: larkincj@tcd.ie
}

\begin{abstract}
Sustainability in the public finances. This was the mantra of the IMF-ECB-EC Troika bailout. How was sustainability achieved? Mainly by changing aspects of the budgetary process. Ireland was required to submit the entirety of its budgetary framework for external scrutiny by the Troika and Eurozone member state governments. We briefly explore how the economic constitution of the European Union in the context of the Irish bailout turned macroeconomic sustainability into an instrument to redirect the majority of Irish policy decision-making out of the hands of democratically accountable parliamentarians and into the arms of unaccountable technocrats.
\end{abstract}

Keywords: Public finances; Troika; Bailouts; Ireland; Government.

\section{The Impact of the Bailout and New Rules}

Sustainability in the Irish public finances was the primary interest of the Troika and the Irish government since the December 2010 bailout plan. It was to be secured by a series of actions that changed the structure of the Irish taxation system but the majority of the correction of the fiscal position was achieved by the nominal fall in public sector wages, decreases in the numbers employed by the public sector and a series of cuts to social welfare and the public capital programme. The advantage of this programme of reform was that it was primarily developed by the Irish authorities in December 2010 and was modified, to a minor extent, by the Fine Gael-Labour coalition in March of 2011. This programme was then followed until the exit of Ireland from the official sector programme in December 2013. The question now is the development of a sustained fiscal future for Ireland. The key challenge is how to secure that fiscal stability but still ensure that there remains 
a democratic structure of accountability. In this paper we look, from a parliamentary perspective, at the Irish experience of the Bailout, the imposition of EU fiscal rules and how the budget process in Ireland has changed as a result of these external and internal pressures.

The reality of the situation is that the Irish fiscal position was determined largely by the November 2010 National Recovery Plan 2011-2015. The Plan predated the involvement of the IMF but was in keeping with many of the recommendations of the Troika. The Letter of Intent of 3 December 2010 stated:

'To continue with the programme of fiscal consolidation, a comprehensive National Recovery Plan 2011-14 was approved by the Government and published on 24 November 2010. This Plan forms the basis for the 2011 budget consistent with fiscal consolidation measures amounting to $€ 15$ billion, a 9 percent of GDP budgetary correction over the period 2011-14. Having stabilised the deficit, albeit at a high level, the steps announced in the Plan will place the budget deficit-to-GDP ratio on a firm downward path. While the debt-to-GDP ratio will remain at high levels for the next few years, it is projected to decline thereafter, underpinning debt sustainability. We also propose to keep under review progress towards meeting the Stability and Growth Pact targets.' (IMF ${ }^{1}, 2010: 7$ )

The Irish approach to fiscal consolidation and sustainability was clouded by the need to make a series of rapid adjustments to the public expenditure space. This was achieved in the 2011 budget by way of a front-loaded $€ 6$ billion in consolidation. Part of the desire was to communicate to the international capital markets the seriousness with which the Irish authorities took this policy.

The view of the IMF official in charge of the programme, Mr.Ajai Chopra, was that Ireland was being overly ambitious at the time of the Bailout with respect to its fiscal targets but understood that this was part of a longer and more complex structure of negotiations related the structure of the Promissory Notes, which supported the Irish Bank Resolution Corporation, and the status of the remaining senior bondholders of the Irish banking system. Chopra made it clear that the sustainability of the public finances was under way as part of the Irish domestic consolidation programme. This progress was in many ways welcomed by the Troika during the December 2010 to December 2013 programme but the Fund did recommend tempering some of the measures to

\footnotetext{
${ }^{1}$ IMF. Ireland: Letter of Intent 3 December 2010. Washington, D.C.: IMF, 2010.
} 
improve the domestic demand and employment situation. Half way into the program, the IMF's 2012 Article IV discussions provided an opportunity to step back and review the approach to fiscal consolidation to ensure that remaining consolidation needs would be met in a manner that was both durable and protected the vulnerable. Ireland did not take this advice at the time and continued a relatively rapid consolidation, largely to achieve EU rules.

The new budgetary process that Ireland had to comply with as a result of these legislative changes is outlined in Figure 1 which illustrates the nature of the Irish government's budgetary process. The most significant developments in the domestic sphere of the budgetary process post Bailout by engaging in extensive EU and domestic oversight in the pre-budget phase. The idea was to place the Irish public finances on a sustainable and EU policy compliant pathway. This is the aim of the expanded fiscal remit of the European Commission, as it rationalized that this will bring greater stability to the currency union (Bénassy-quéré and Ragot [2016]; Niemann and Ioannou [2015]; and Schmidt [2016]). Figure 2 illustrates how this is supposed work for the purposes of policy coordination.

\section{Insert Figure 1 and 2 about here}

The semester adds a new dimension of oversight from the European Commission. The key component is the 'country specific recommendations' or CSRs provided by the Commission for the purposes of developing a sustainable approach to the public finances. Most of the recommendations relate to two areas. First, those that will direct the country in question towards a position of structural budget balance. The other is towards supply-side measures that will improve the overall competitiveness of the economy under review.

\section{Insert Figures 3 through 7 about here}

The modifications to the budget process have made for a much more complex approach to budgeting, based on a combination of hard and soft fiscal rules incorporated into constitutional law or into normal statutes. These rules, except for the statements made by the Fiscal Advisory Council, inhabit the environment of hard law. That is, they are clearly incorporated into the legal structures of Ireland and must be acknowledged and adhered to within the parameters of legislative direction. 
The Fiscal Advisory Council, created as part of the conditionality of the Troika Bailout, has a statutory basis for existence but its actions, recommendations and reports. The Advisory Council's authority comes more from moral suasion than legal obligation and the present government has adopted an á-la-cart approach to applying recommendations. Figures three through seven illustrate the structure and design of these new fiscal rules and how they interact with the traditional budget process.

\section{The Role of Parliament}

The Irish parliament, like most traditional Westminster-models, reserve the power over tax and expenditure to the lower house of parliament within a bicameral system. In the case of Ireland this is referred to as Dáil Eireann. The upper house, Seanad Eireann, has very limited capacity to make recommendations to the budget items. The Dáil, made up of 166 members, has an executive, from which the Minister for Finance is drawn. Since the 2011 election, matters related to the budget have been distributed between the Minister for Finance, responsible for taxation, macroeconomic management, banking and financial regulation and ECOFIN meetings, and the Minister for Public Expenditure and Reform, responsible for the allocation of expenditure to different parts of the public sector. The Joint Oireachtas Committee on Finance, Public Expenditure and Reform is responsible for reviewing the budget, and most closely the Finance Bill, and engaging in a process of filtering requests from interest groups and civil society into the budgetary process. The Public Accounts Committee engages in ex post evaluation of expenditure. This budget structure is reactive, most responding to policy initiatives begun by the Minister for Finance. The new budgetary frameworks provided by the European Union fiscal rules along with the structure of the IMF bailout package severely limited the input of the parliament in the budget process. This poses some series issues for the future role of democratic accountability.

Since the start of the process of fiscal consolidation that began shortly after the September 2008 Banking Guarantee, the Irish government began a process of consolidating the public finances. Such emergency measures were largely crafted within the Department of Finance and then presented by then Minister for Finance Brian Lenihan to the parliament for approval. Given the Westminster model, the political structure of Ireland ensured that these measures were accepted. The political response to the Troika Bailout in December 2010 was to move towards a general election, which took place in February 2011 and the new government largely accepted the reform programme 
presented by the Irish civil service and the Troika. Since exiting the bailout in December 2013, much has been made of Ireland's renewed economic sovereignty. Ultimately the changes made by EU fiscal rules limit the effectiveness parliamentary oversight and the influence of civil society on adding to budgetary measures. Even in the waning days of the previous Fianna Fail-Green coalition government, some semblance of party discipline remained and the imposition of the party whip remains a strong tradition in the Irish parliament. As a result the ability to vote against the party which one is a member is extremely limited, as there is no constitutional right to a so-called 'free-vote' in the Irish parliament, as there would exist in the German Republic or many recently transitioned Central and East European Counties. Under these conditions the role of parliament as a source of oversight and with a view towards sustainability and critique of mainstream policy decisions is extremely limited.

\section{Insert Figure 8 about here}

This does not mean that the political system at the parliamentary level does not attempt to posture greater influence than it may have at any one given point in time. There exists an uneasy tension between the professional civil service and the members of the political class in all parliamentary environments. In the Irish context this is exacerbated by the political outcome of the 2010 Bailout. As presented in Figure 8, the Fianna Fail-Green Party coalition lost on an almost revolutionary scale with the Green Party losing all its parliamentarians and Fianna Fail losing 77 seats. The political class, both winners and losers from 2011, see the lack of accountability suffered by the civil and public service as an ongoing sore point and the operation of the Public Accounts Committee (PAC), with ex post budgetary oversight has been part of the response. This has incurred legal responses from various individuals who have been placed before the PAC. These legal responses, in conjunction with several banking crisis civil and criminal actions (Corbet [2016]) remain sub judice limited the capacity of the Banking Inquiry to question public and private sector actors.

\section{Where Next for Parliaments?}

The Irish case study is a clear example of how quickly the nexus of politics and professional economic policymaking can work to exclude the legislature. The legislature becomes a token ele- 
ment of legitimization for decisions made by others. In the context of the Irish parliament this was done partly by executive structures that existed as part of the Taoiseach's office, cabinet collective decisions, the role of the senior civil service, the role of supranational bodies and officials and senior political figures from friendly countries. In all these contexts the general 'rules of the game' as outlined by law and legal precedent work to general limit the extent to which parliaments can interfere with policy that is either the product of technocratic analysis or the European economic constitution.

In this context the parliamentarian is effectively defunct. The role of the parliamentarian is to act as an information conduit into the policymaking process but not to partake in it. As it stands the effectiveness of that role as communicator can only exist to a greater of lesser extent as a function of access to senior cabinet figures. While it may seem keenly fatalist to come to this conclusion it is important to note that it is drawn from a series of responses on the part of the electorate, the law courts and supranational institutions to the real and perceived failures and weaknesses that exist with the capacity for parliament and parliamentarians to achieve sustainable, corruption-free, legally-justifiable, equitable decisions on matters relating to the public purse.

The current economic constitution of Europe does not afford the parliamentarian or the senior minister or domestic official much run for free budgetary decisions. This is seen as a necessary condition to the maintained of the monetary union. But one problem remains - who should decide how we order the economic and fiscal components of our society? Is it the people? It is their representatives? Is it the technocrats? Is it a wider 'system' outside and above the nation-state? At no point during the Global Financial Crisis or during the post-1989 period were these questions adequately posed or answered. The situation most Western governments find themselves in now, especially Ireland, is one brought about by ad hoc responses to events and inertia - legal, administrative, political and economic.

The current role of the parliamentarian needs to be redefined, much like it was in the midnineteenth century following the Great Reform Act in the UK. Sustainability will have to be part of that process of redefinition but also scrutiny. 


\section{Conclusion}

This paper has outlined some of the radical changes that have taken place in the fiscal space in Ireland as a Troika Bailout country since 2010. The changes are profound at the institutional level but also have had deep political effects, changing the nature and role of parliament in the process. This is a perspective draw from a practitioner in parliamentary policy circles in Ireland. It mostly asks questions related to the unspoken changes that have taken place over the past decade since the start of the Global Financial Crisis. We have outlined the changes made in practice and law to the process of budget formation and decision making. We have framed the new role of the parliamentarian in this process and presented where the challenges lie ahead for any new parliament coming to power in Ireland and in other countries. Ultimately the challenges that exist for the role of parliament in sustainable budget policymaking need to be addressed if there is to be a continued role for the people in deciding the character of the societies and economies in which they reside. The public finances are too important to leave solely in the hands of technocrats, the executive or the legislature alone.

\section{Bibliography}

Banerji, A., B. Barkbu, J. John, T. Kinda, S. Saksonovs, H. Schoelermann, and T. Wu (2015). Building a Better Union: Incentivizing Structural Reforms in the Euro Area. IMF Working Paper (201), 1-40.

Bénassy-quéré, A. and X. Ragot (2016). Which Fiscal Union for the euro area? Bruegel Policy Contribution (5), 1-17.

Corbet, S. (2016). Turning Tigers into PIIGS: The Role of Leverage in the Irish Economic Collapse. Advances in Sustainability and Environmental Justice.

Niemann, A. and D. Ioannou (2015). European economic integration in times of crisis: a case of neofunctionalism? Journal of European Public Policy 22(2), 196-218.

Schmidt, V. A. (2016). Reinterpreting the rules 'by stealth' in times of crisis: a discursive institutionalist analysis of the European Central Bank and the European Commission. West European Politics 39(5), 1032-1052. 
Figure 1: The Role of Parliament in the Budget Process
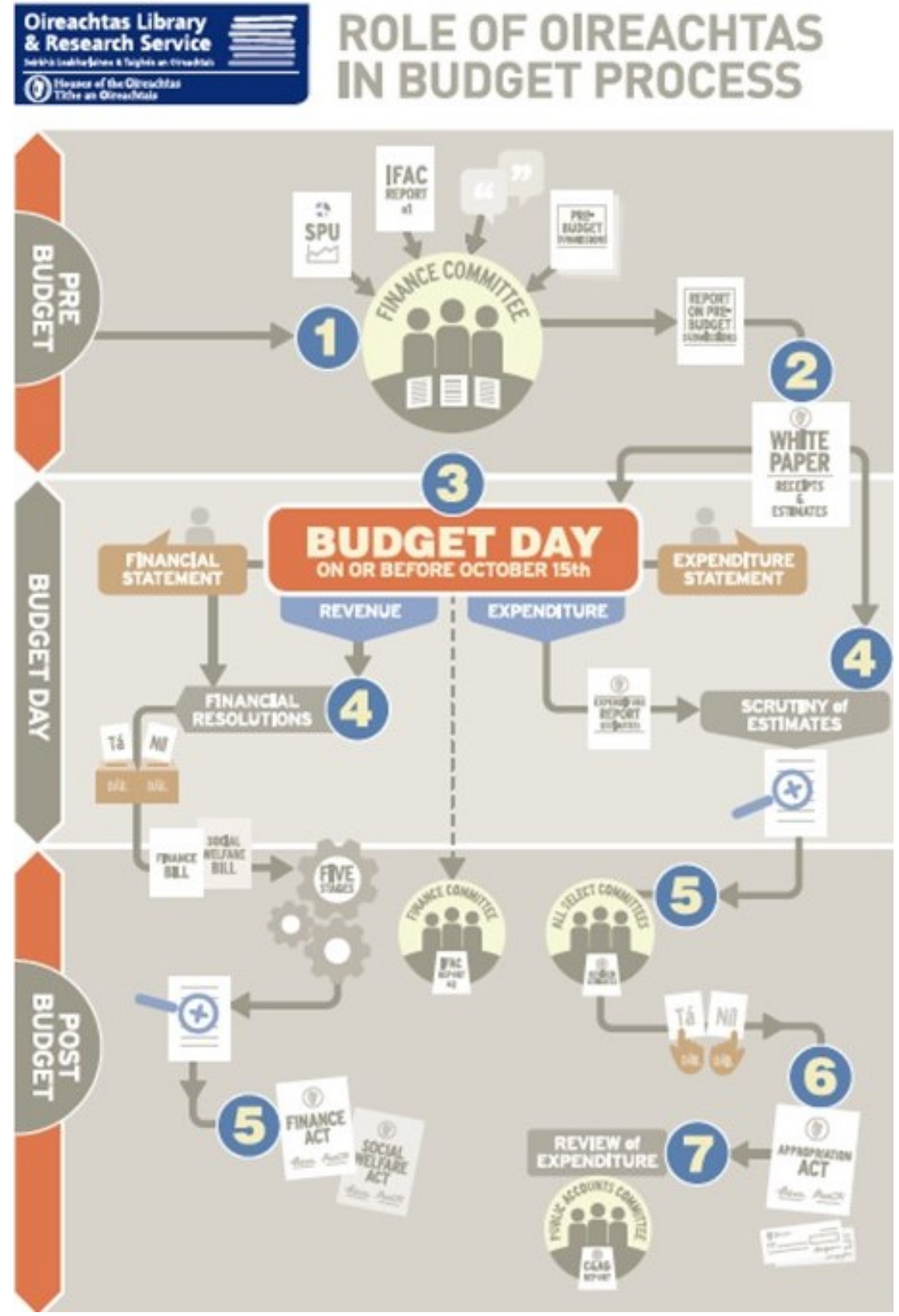

Source: Oireachtas Library and Research Service, 2014. 


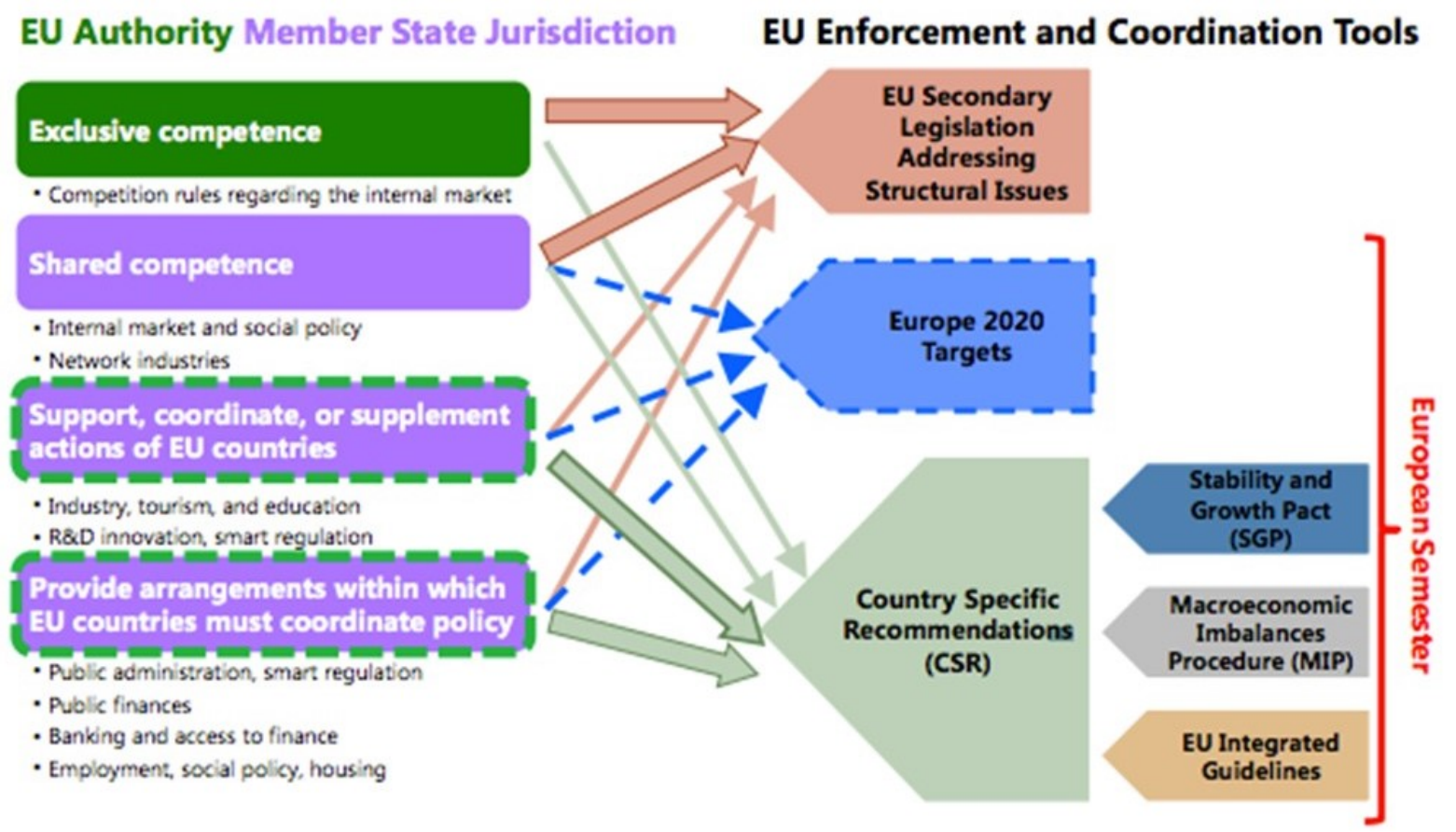

Source: Banerji et al. [2015] 
Figure 3: EU Economic Governance Rules âĂŞ Legal Basis

\section{New European Economic Governance Rules}

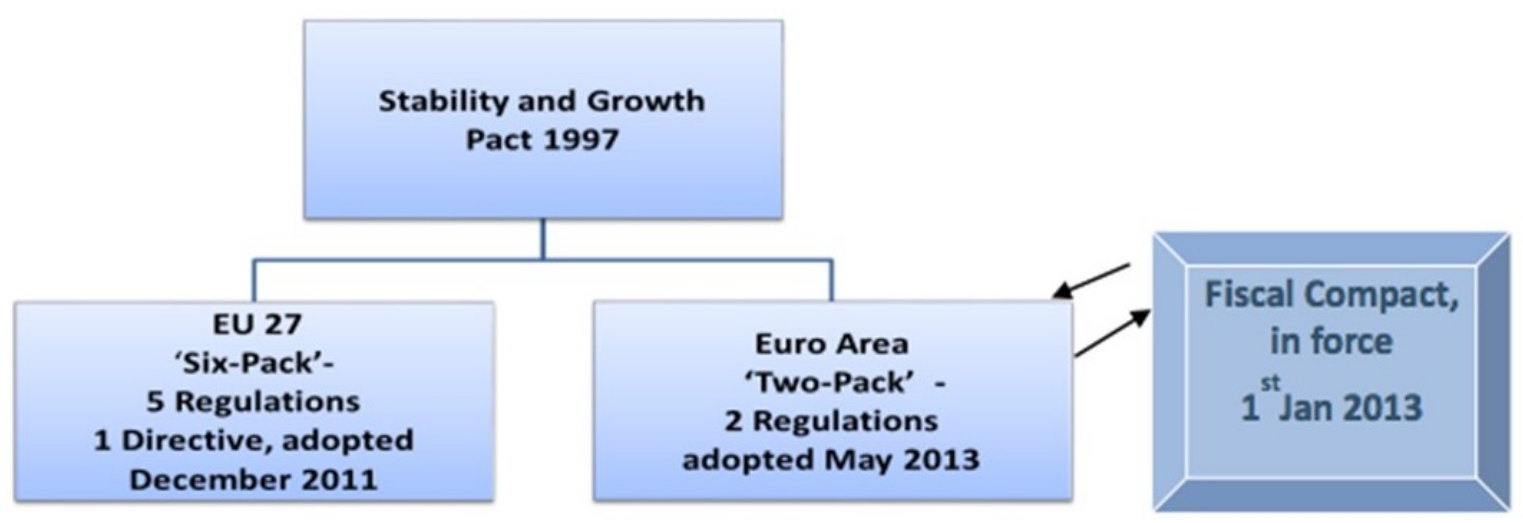

Source: Department of Finance. Medium Term Budgetary Framework, 2014. 
Figure 4: Internal Budget Process followed by the Department of Finance and Department of Public Expenditure and Reform

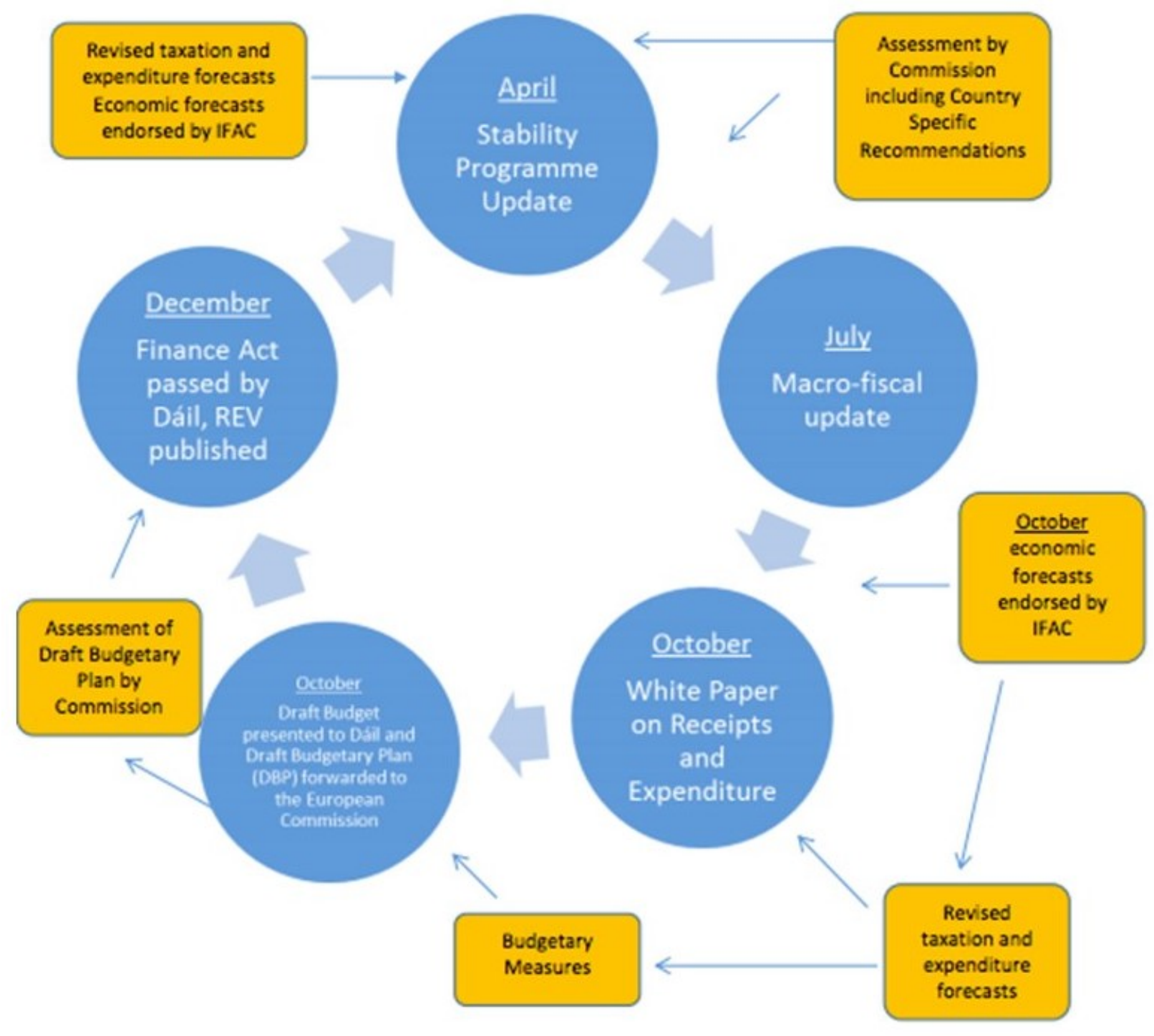

Source: Department of Finance. Medium Term Budgetary Framework, 2014. 


\begin{tabular}{|c|}
\hline $\begin{array}{l}\text { Oireachtas Library } \\
\text { \& Research Service }\end{array}$ \\
\hline 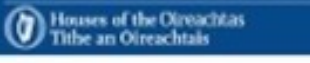 \\
\hline
\end{tabular}

2-Pack

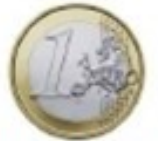

Applies: eurozone-18
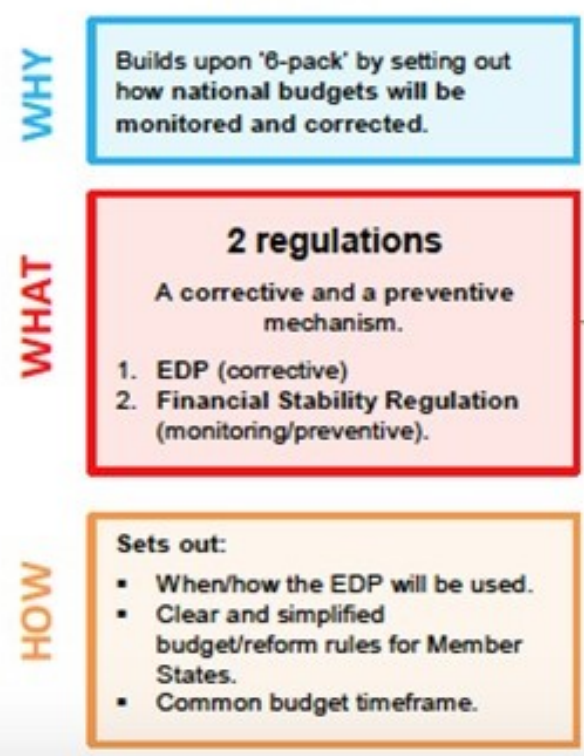

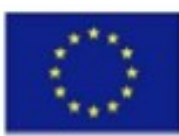

Applies: EU-28

To coordinate EU national budgets and economic policies to prevent

issues like housing bubbles

reoccurring (called 'macro-economic imbalances").

\section{5 regulations and 1 Directive}

1. Fiscal/Budgetary: Strengthen the SGP (stricter rules) and EU surveillance of national budgets.

2. Macro: Monitor and control largescale (macro-) economic imbalances).

Sets out:

Preventive arm: National budgets must follow

- Medium-term plans (MTO)

- SGP rules

...or face penalty via Excessive Deficit Procedure (EDP) or the Macro-Imbalance Procedure (MIB) corrective arm.

\section{Stability and Growth Pact} (SGP)

Deals with fiscal governance of European Monetary Union (EMU).

Rules for the euro area:

1. Budget deficits must not exceed $3 \%$ of GDP.

2. Level of public debt must not exceed $60 \%$ of GDP.

A corrective mechanism known as the Excessive Deficit Procedure (EDP) is used for breaches. 
Figure 6: Flowchart of the European Semester following new fiscal rules

\section{Who does what in the European Semester?}

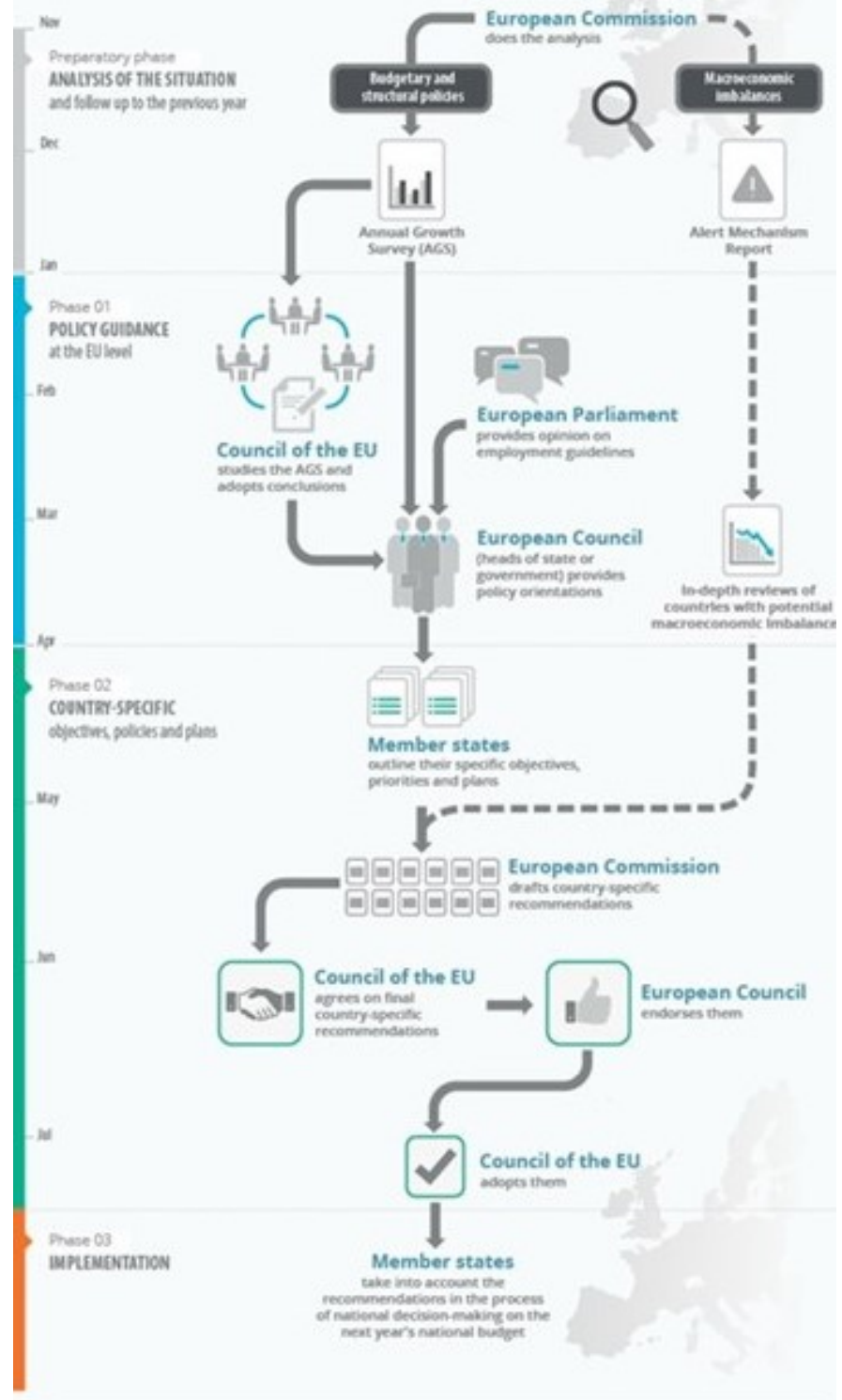

A new cyele starts again towards the end of the year, when the Commission gives ary overview of the economic situation in its Annual Growth Survey for the coming year.

Source: http://www.consilium.europa.eu/en/policies/european-semester/ 


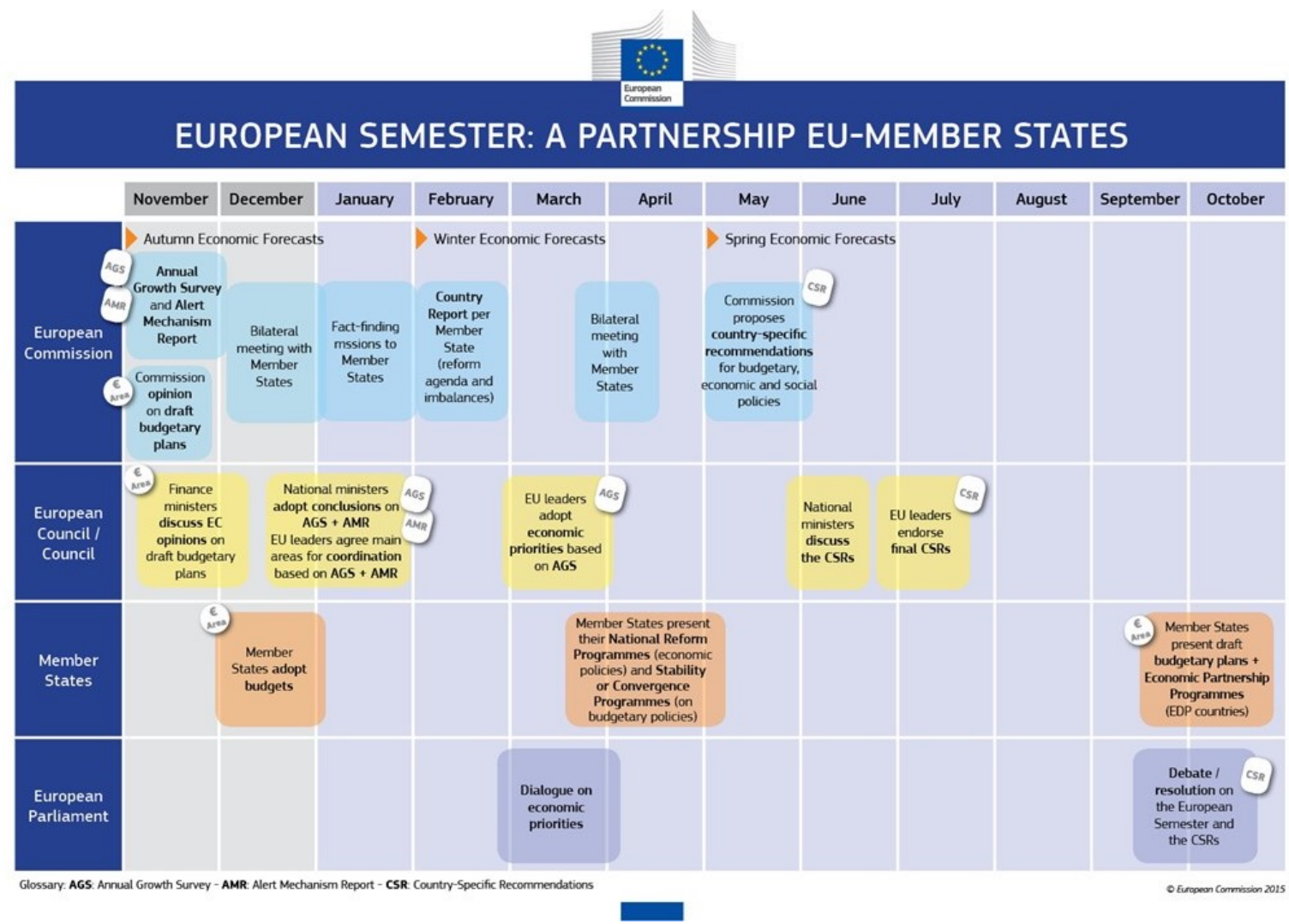

Source: http://ec.europa.eu/europe2020/images/european_semester_en_big.jpg 
Figure 8: First Preferences, 2007 General Election and 2011 General Election

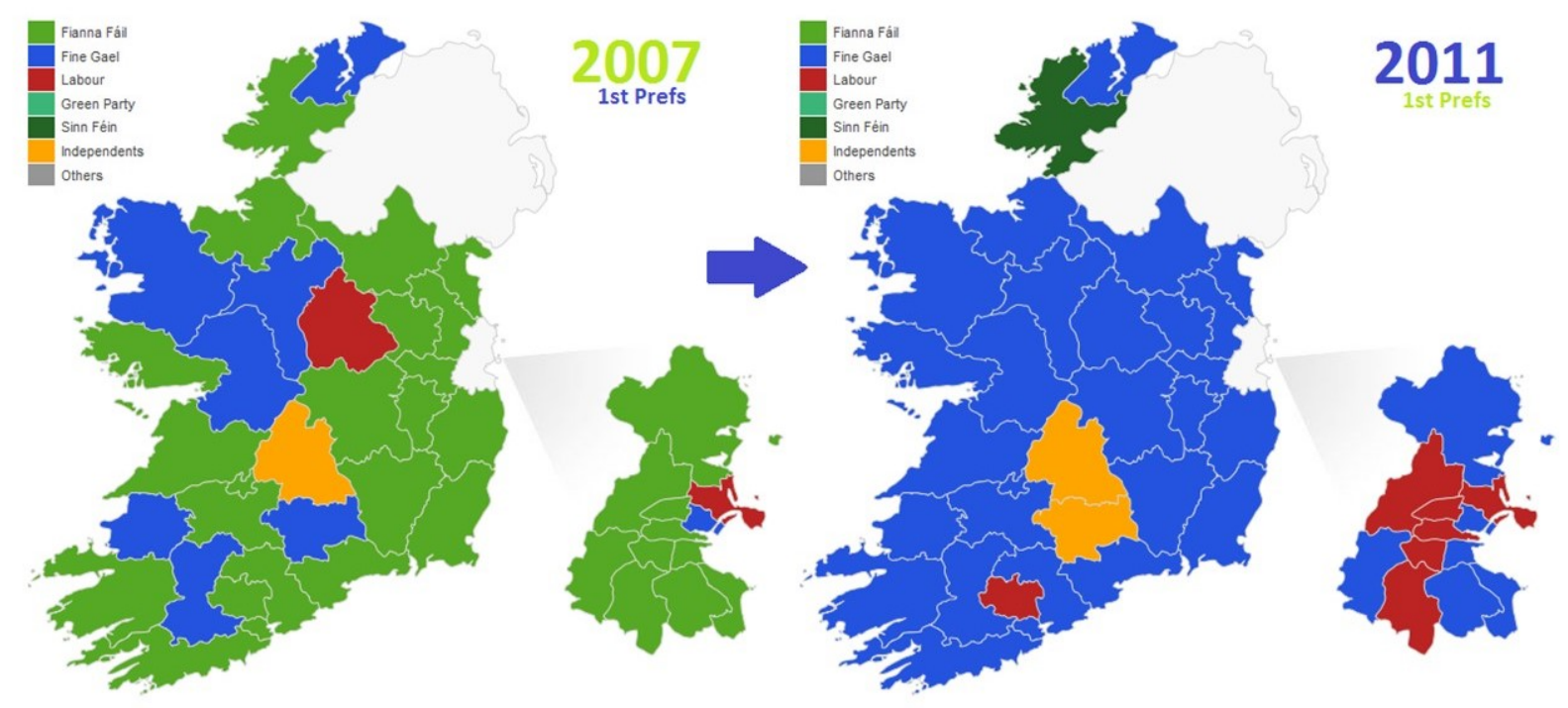

Source: Irish Times Ltd. Election results: General Election 2011. 